\title{
Síndrome congênita do Zika vírus: um olhar a partir de atores nordestinos
}

\author{
Congenital Zika syndrome: views from Northeast Brazil \\ Síndrome congénito del virus Zika: perspectiva a partir de actores \\ del Nordeste de Brasil
}

ZIKA: DO SERTÃO NORDESTINO À AMEAÇA GLOBAL. Diniz D. Rio de Janeiro: Civilização Brasileira; 2016. 192 p. ISBN 978-85200-1313-7

doi: 10.1590/0102-311X00184017

Entre fevereiro-junho de 2016, Débora Diniz, ao participar de grupo de trabalho da Organização Pan-Americana da Saúde, depara-se com um quadro grave, de importância internacional, e decide realizar pesquisa etnográfica pelo sertão nordestino brasileiro. Busca compreender a realidade de mulheres anônimas que perderam a alegria do pré-natal, após descobrirem que seus filhos haviam sido infectados por um mal ainda desconhecido.

O livro investiga fatos históricos de atores do Nordeste: médicos de beira de leito, pesquisadores que se surpreenderam com um novo vírus e mulheres que sofriam a angústia de um diagnóstico cruel, determinante em suas vidas e na de seus filhos. Além disso, apresenta-se levantamento baseado em documentos e em notícias de veiculação nacional e internacional, desde a identificação do vírus zika e a sua transmissão vertical até sua relação com a microcefalia e a síndrome de Guillain-Barré. A repercussão dessa obra tem sido tão grande que, em outubro de
2017, ela recebeu o primeiro lugar no 59o Prêmio Jabuti, a mais importante premiação literária do país, na categoria Ciências da Saúde 1 .

A autora discute hipóteses sobre a chegada do vírus ao país, contrapondo "cientistas de jaleco branco" a "médicos de beira do leito", que têm percepções distintas sobre qual dos eventos mundiais, entre 2013 e 2014, teria trazido o vírus. Ademais, faz um alerta sobre a manutenção do vetor no país há cerca de quarenta anos, decorrente do quadro sanitário que favorece a sua rápida disseminação no território.

Parte dessa história é demonstrada no documentário Zika 2, no qual Débora acompanhou cinco mulheres grávidas paraibanas infectadas pelo vírus, com suas lutas e angústias, e o quadro de desigualdade e injustiça social que as envolvia.

O Nordeste é visto como o "epicentro da epidemia da síndrome congênita do zika” (p. 133), ressaltando-se Pernambuco e Paraíba como os estados que tiveram maior concentração de casos. Observa-se o drama das famílias que percorrem grandes distâncias e enfrentam inúmeras dificuldades para conseguir atendimento especializado, sem o amparo devido do Estado. A autora ainda critica a forma como estão sendo tratados os direitos das mulheres e as questões reprodutivas: "nenhuma política de saúde séria pode considerar abstinência sexual e infecundidade como recomendações razoáveis para a saúde reprodutiva ou para o controle de uma epidemia com múltiplas formas de transmissão” (p. 140). 
Nesse sentido, cabe destacar alguns capítulos, por exemplo, A Epidemia da Alergia, que expõe a investigação da equipe de médicos nordestinos de Alagoas, Rio Grande do Norte e Pernambuco que, em parceria com o Paraná, foi a primeira a publicar sobre o isolamento do vírus zika no Brasil. A Doença Misteriosa conta a descoberta do vírus na Bahia. Primeiras suposições apontavam para contaminação de água em Camaçari. Depois de esclarecido o mistério e divulgados à imprensa os achados da pesquisa, positiva para zika, a equipe foi questionada quanto à fidedignidade dos seus estudos. $\mathrm{O}$ capítulo As Neuropediatras de Recife demonstra a relevância de profissionais que se inquietaram com o nascimento de crianças, em um curto período, com um padrão típico de adoecimento. Elas foram responsáveis pelo registro de sinais e sintomas que receberam a nomenclatura de síndrome congênita do zika. A Médica do Cariri narra a preocupação de uma obstetra diante de um quadro nunca antes visto em suas ecografias, ao longo de mais de 20 anos de experiência. Após pesquisa com líquido amniótico de gestantes e divulgação dos resultados, o pronunciamento oficial não lhe deu a honra da descoberta.

A autora critica a corrida científica e a competitividade pelos louros da descoberta: "é um jogo por reconhecimentos, vantagens e futuros de pesquisa" (p. 65). Entretanto, sua sensibilidade evidencia os verdadeiros atores da história: nordestinas anônimas que não aparecem nas publicações, que sentiram na pele a nova virose e perseguiram profissionais de saúde para resolução dos seus tormentos físicos.

Dentro dessa perspectiva, A Primeira Geração de Mulheres refere-se às primeiras grávidas infectadas com zika, destacando duas mães que passaram pelo sonho da maternidade, colaboraram com a pesquisa científica, submetendo-se a viagens, exames e questionários intermináveis. Elas receberam o mesmo diagnóstico e prepararamse como puderam para o dia do nascimento, entretanto, uma das crianças não sobreviveu e, ainda enlutada, a mãe o oferece à pesquisa científica.
O Paciente Zero relata o caso do primeiro recém-nascido no Brasil detectado com o vírus zika durante a gravidez. É "o primeiro paciente que fez a medicina despertar para a novidade” (p. 129). Curiosamente, apesar de se tratar de uma gravidez de gêmeos bivitelinos, uma das crianças não foi afetada. A família enfrenta desafios e dúvidas sobre a possibilidade de alterações neurológicas futuras no gêmeo não afetado.

Em A Ameaça Global, Débora relembra o anúncio de Emergência de Saúde Pública de Importância Internacional e preocupa-se com a transmissão da doença por um vetor comum em circulação, trazendo risco imediato ao planeta. Os Jogos Olímpicos no Rio de Janeiro poderiam ser fator preponderante para a disseminação do vírus e para o desespero de mulheres no mundo inteiro. Nossos líderes, em vez de agirem na efetivação de políticas públicas de saneamento e habitação para melhoria de condições sanitárias, pedem que se evite exposição do corpo e que se use repelente. A maior ameaça é a grande preocupação com mosquitos, em detrimento da preocupação com mulheres: "se a epidemia do zika ultrapassar as fronteiras dos países com transmissão autóctone, o tempo da gravidez será de aflição para as mulheres do mundo, tal como já é para as mulheres nordestinas" (p. 151).

O fim da emergência, decretado pela Organização Mundial da Saúde em fevereiro de 2017 e pelo governo brasileiro em maio de 2017, trouxe ainda mais preocupação à pesquisadora. Contra a medida, declarou: "as mulheres do Zika foram esquecidas" 3. Os casos são reduzidos a números para notificação ou confirmação, e o silêncio sobre essas mulheres prevalece ${ }^{4}$. Mulheres e crianças continuam sem garantia de direitos sociais, pois diante dos benefícios prometidos pelo governo para dar assistência às famílias atingidas, sobram promessas e faltam ações, desde o cuidado precoce até dificuldades de transporte e alimentação.

O torpor dos meios de comunicação, essa aparente calmaria que se instala pós-epidemia, não faz sentido e mascara a realidade nua e crua diante de nós. O que esperar para as próximas gerações? Métodos ineficazes e arcaicos para o 
combate ao vetor, aprofundamento de desigualdades sociais e sanitárias, resultando em novas epidemias e manutenção de doenças já existentes, descaso quanto a essas vidas e às próximas que virão?

Em suma, percebe-se que, sem dúvida, a obra é um marco, destacando-se pelo detalhamento da história do vírus zika e sua transmissão vertical e pelo olhar sensível e aguçado para os protagonistas dessa descoberta, sobretudo mulheres nordestinas que encaram, temerosamente, o período gestacional e incertezas sobre como será o futuro de seus filhos. Que a apatia do momento presente não gere outras histórias sofridas. A história que nos perpassa precisa servir de exemplo para transformação e mudanças. As vítimas dessa tragédia sanitária não podem e não devem ser esquecidas.
Natália Lira de Souza 1

1 Instituto Aggeu Magalhães, Fundação Oswaldo Cruz, Recife, Brasil.

nataliaglira@hotmail.com

1. Prêmio Jabuti. http://premiojabuti.com.br/ apuracao/f2-dt311017-1507/\#1 (acessado em 20/Nov/2017).

2. Diniz D. Zika. https://youtu.be/m8tOpS515dA (acessado em 19/Nov/2017).

3. Diniz D. As mulheres do zika foram esquecidas. https://www.cartacapital.com.br/sociedade/asmulheres-do-zika-foram-esquecidas (acessado em 21/Nov/2017).

4. Diniz D. Vírus Zika e mulheres. Cad Saúde Pública 2016; 32:e0046316. 